\title{
Research Article: Preferences of post graduate agricultural students regarding instructional methods
}

\section{N. MRIDULA}

Article Chronicle : Received :

29.09.2015;

Revised :

13.10.2015;

Accepted :

27.10.2015

KEY WoRds:

Instructional

methods, Student

preferences, Active

learning, Agricultural

science

Author for correspondence :

\section{N. MRIDULA}

Centre for E-learning,

College of Horticulture,

Kerala Agricultural

University,

VELLANIKKARA

(KERALA) INDIA

Email: mridulanarayanan

@gmail.com
SUMMARY : The student perceptions and preferences regarding the suitability of various instructional methods reveal the effectiveness of the each teaching method in their respective fields of study. A study conducted among the post graduate agricultural students, belonging to life science and social science streams, of Kerala Agricultural University disclosed their preferences regarding the presently followed instructional methods. It was found that both life science and social science students showed favourable attitudes towards active learning methods like discussions, practical sessions, demonstrations and field visits. The findings of the study and the suggestions put forward by respondents will help the agricultural universities to look into their instructional methods and modify the curricula in ways that would improve student learning.

How to cite this article : Mridula, N. (2015). Preferences of post graduate agricultural students regarding instructional methods. Agric. Update, 10(4): 351-354. 